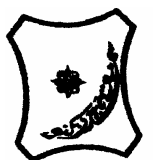

Bayero Journal of Pure and Applied Sciences, 6(2): $10-18$

Received: March 2013

Accepted: September 2013

ISSN $2006-6996$

\title{
RELATIONSHIP BETWEEN SPECIES COMPOSITION AND HOMEGARDEN SIZE IN ODEDA LGA OF OGUN STATE NIGERIA
}

\author{
*Aworinde, D.O. and ${ }^{1}$ Erinoso, S.M. \\ *Department of Biological Sciences, Ondo State University of Science and Technology, Okitipupa, Nigeria \\ ${ }^{1}$ Department of Botany, University of Ibadan, Ibadan, Nigeria \\ Correspondence author: davidaworinde@yahoo.com
}

\begin{abstract}
Studies on correlation between species composition and homegarden size in thirty (30) house gardens in Odeda Local Government Area of Ogun State, Southwestern Nigeria was conducted. Plants grown and maintained by household members and the diversity of vegetal species and their uses were assessed using semi-structured questionnaire and structured interview. A total of 120 different plant species belonging to 50 Families were documented. From the data, Euphorbiaceae, Solanaceae, Rutaceae, Malvaceae, Caesalpiniaceae, Poaceae and Apocynaceae (in order of decreasing number of species) were the most frequent Families. Taxa such as Musa species, Vernonia amygdalina, Citrus species, Psidium guajava and Terminalia catappa were found to be the common food/medicinal plants as evidenced by their densities in the study sites. The household members cited most of the plants as food; others as medicinal and ornamentals. Miscellaneous uses include cosmetics, ceremonial and scouring. Homegarden products serve alimentary purposes and represent promising base materials for poverty alleviation and may also help to augment "fresh" food nutrient intake. Pearson Correlation analyses indicated no statistically significant association between species composition and homegarden size (Simple correlation=0.289, $P=0.122)$. Species composition and homegarden structures as well as plant uses are discussed. Key words: Homegarden, Odeda, Southwestern Nigeria, Species composition
\end{abstract}

\section{INTRODUCTION}

Homegarden has a significant social function. It represents land-use systems involving deliberate management of multipurpose trees and shrubs in intimate association with annual and perennial agricultural crops and invariably livestock within the compounds of individual houses (Fernandes and Nair, 1986) and are the central points of biodiversity conservation. Homegardens are traditional agroforestry systems with complex structure and multiple functions (Das and Das, 2005) and are viewed as an alternative to the ever increasing demand for food (Soemarwoto et al., 1985) particularly in West Africa. Hoogerbrugge and Fresco (1993) defined homegarden as "a small scale, supplementary food production system by and for household members that mimics the natural, multilayered ecosystem". An addition to the definition to include the role of medicinal plants by Agelet et al. (2000) is worth considering.

Investigations on Agroforestry in tropical areas have focused on homegardens; reports from these have been described as prototype for sustainable ecological systems (Albuquerque et al., 2005; Lamont et al., 1999; Padoch and De Jong, 1991). Species diversity in tropical homegardens is reported to be very high due to species having different life forms, height and canopy structure (Babu et al., 1982; Soemarwoto and Conway, 1991). Research involving biological diversity in rural communities has intensified in recent years and its scope now extends to the semi-urban centres but mainly to locales that maintain richness of vegetation and animals such as parks, arboretum and flower gardens. The species diversity sheltered by these locales provide resources and alternative resources for food, decoration, construction and medicinal uses (Brito and Coelho, 2000; Semedo and Barbosa, 2007; Amaral and Guarim-Neto, 2008), as well as contributing to flood control and protecting against soil erosion (Soemarwoto, 1987). With the development of the environmental sciences, scientists have now understood the significance of the relationship between humans and nature in the rural and/or urban environment. As a matter of fact most previous studies were carried out in temperate regions; forests (tropical) may be considered the orphans of the Nigerian eco-region.

Recently, just as in Agro-forestry, Ethnobotany (as a discipline) has dedicated increasing attention to the theme of conservation of homegarden biodiversity. The diversity found in homegardens is a source of genetic variability that has been accumulated by the local populations, constituting a valuable patrimony for food security and even a source of genetic material for the improvement of species for commercial purposes (Soemarwoto et al., 1985; Valle, 2000). Structure and floristic composition vary in homegarden establishment.

This study, part of a wider project on ethnobotany in the Nigeria biome, is designed to contribute to our knowledge about the structure, usage and floristic composition of home gardens located in the Southwestern Nigeria, the relationship between homegarden size and species composition, the diversity of plant life form and the floristic variation 
associated with native plant use. This paper provides useful reference on the biodiversity of home gardens and the need for their conservation.

\section{Hypothesis:}

There is no significant relationship between species composition and home garden size.

\section{METHODS}

\section{Study area}

This study was carried out in Odeda Local Government Area of Ogun State Nigeria (Fig. 1). The local government has a land area of $1547.29 \mathrm{~km}$ square with a population of 109, 449 (NBS, 2006). The headquarters of the LGA is at Odeda on the A5 highway $7^{\circ} 13^{\prime} 00^{\prime \prime} \mathrm{N} 3^{\circ} 31^{\prime} 00^{\prime \prime} \mathrm{E}$. The climate favours the cultivation of a wide range of food crops such as rice, maize, cassava, yam, cocoyam, oil palm, vegetables and fruit trees. The economy of the areas studied is subsistence. However, surpluses are taken to markets or neighbouring towns.

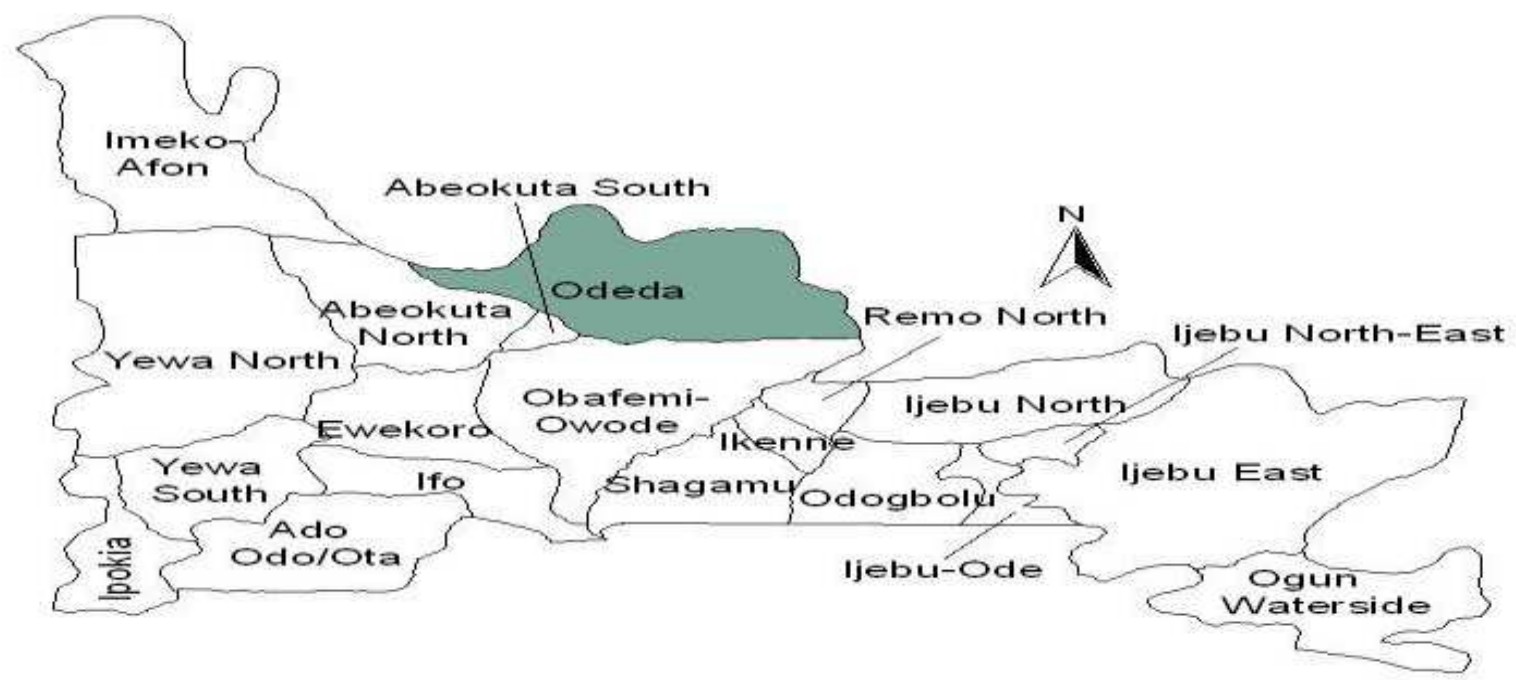

\section{Informed consent}

The purpose of the study was explained to household members in the Local Government Area. Informed consent was obtained from each of the respondents.

\section{Floristic study}

Fieldwork was conducted between March 2012 and June 2012 in Odeda, Southwestern Nigeria. Locations selected for the survey were Obantoko, Osiele, Odeda, Olodo, Ageri, Adewusi, Kila and Orile-Ilugun (Fig. 2). A
State, Nigeria showing the study area.

total of 30 homegardens were surveyed and household members interviewed using semi-structured questionnaire to gather information on the uses of the species present in the gardens. The questionnaire was in two sections. Section 1 dealt with basic demographic information. Section 2 consists of species present, local name, plant form, parts used and uses. Plant specimens were collected and identified in the field. Specimens not identified in the field were taken to Forestry Herbarium, Ibadan (FHI) for identification.
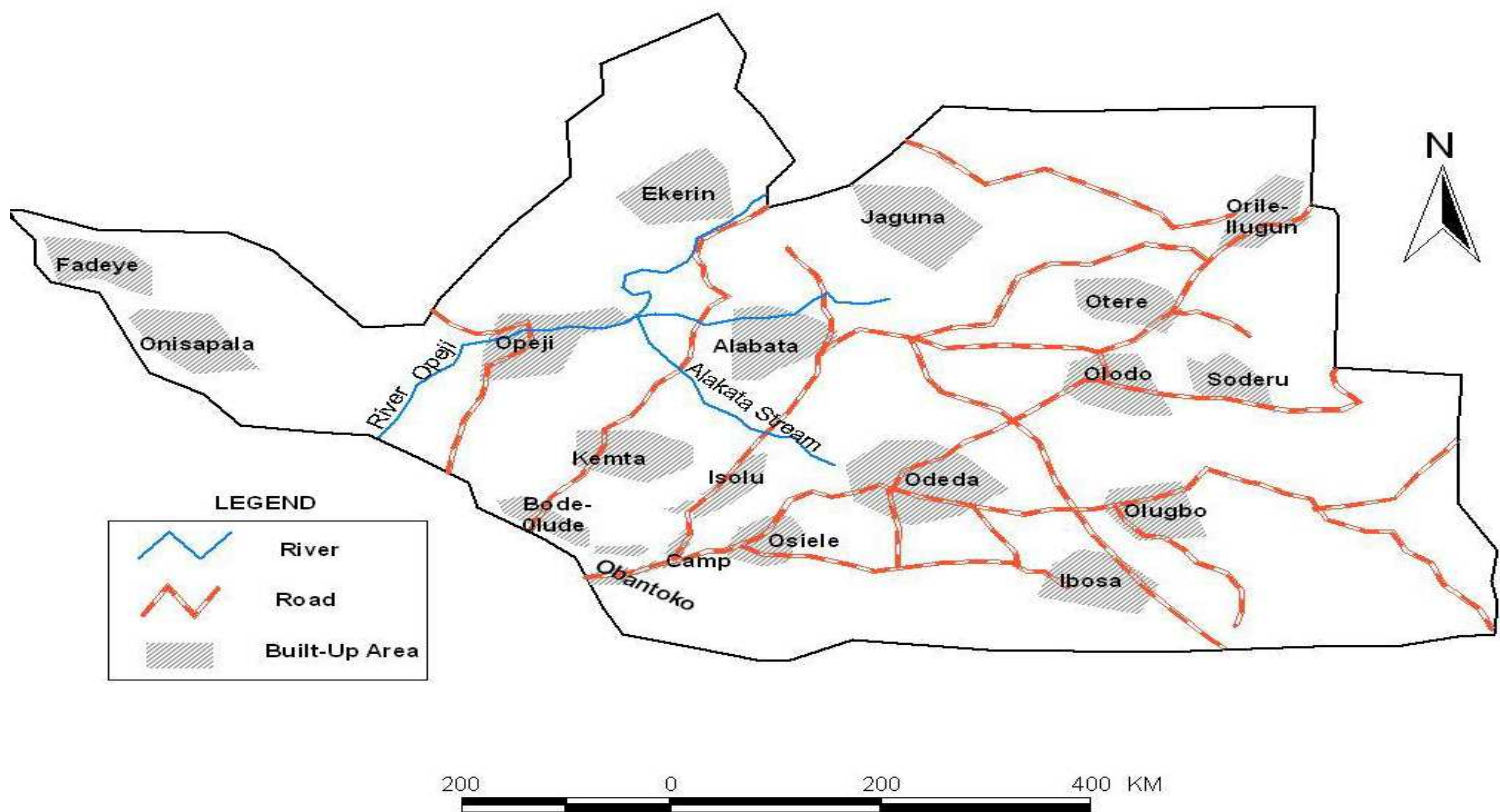

Figure 2: Geographical localization of the study sites. Source: Taiwo et al. (2011). 


\section{Data analysis}

Data obtained from the questionnaires were entered into the computer and analyzed using Epi6-info version 6.04 (CDC, Atlanta, GA, USA) (Dean et al., 1994). Inferential statistical technique used to analyze data was Pearson Correlation Analysis.

\section{RESULTS}

The majority of the respondents were females (Table 1 ). The level of education of household members interviewed ranged from Primary School Certificate (PSC), Junior Secondary School Certificate (JSSC), senior category (SSC), Nigeria Certificate in Education (NCE) to First Degree (FD). The ethnic groups identified are the Yoruba and Igbo. The latter incorporates the Nupe (from Benue State). All the interviewed members are lettered but a good percentage are self-employed.

Table 1: Demographic structure of respondents.

\begin{tabular}{llc}
\hline Parameter & Specification & $\mathbf{N}(\%)$ \\
\hline Age & $1-20$ & $0(0)$ \\
& $21-40$ & $8(26.7)$ \\
Gender & $41-60$ & $12(40)$ \\
& $>60$ & $10(33.3)$ \\
Religion & Male & $12(40)$ \\
& Female & $18(60)$ \\
& & \\
Level of Education & Christianity & $15(50)$ \\
& Islam & $8(26.7)$ \\
& Traditional & $7(23.3)$ \\
& & $16(53.4)$ \\
Nationality & PSC & $1(3.3)$ \\
& JSSC & $7(23.3)$ \\
Ecthnic Identity & SSSC & $2(6.7)$ \\
& NCE & $4(13.3)$ \\
& FD & $30(100)$ \\
& & $0(0)$
\end{tabular}

$\mathbf{N}=$ Number of respondents, $\%=$ Percentage of respondents

Homegardens studied proved to be a basic agroforestry system mainly to hold food, medicinal and ornamental plants, and occupied an area between $53 \mathrm{~m}^{2}$ and $583 \mathrm{~m}^{2}$ with a mean of $158.5 \mathrm{~m}^{2}$ and standard deviation 162.42. The shape, size and number of species varied for each homegarden but were most commonly rectangular $(63 \%)$; square $(13.3 \%)$ (not perfect), triangular (3.3\%). Irregular shapes $(20 \%)$ were also identified. Structurally, vertical dimension took the largest percentage $(53.3 \%)$ while horizontal $(26.7 \%)$ and random settings (20\%) were also encountered. All the species sighted were reported to be useful for several purposes. The respondents cited most as alimentary
(40\%). Others as medicinal (28\%), ornamental $(25 \%)$, shade $(4.7 \%)$ and miscellaneous uses $(2.3 \%)$. Some plants considered as food are also used in culinary while some others serve both as fruit plants and shade such as Terminalia catappa, Mangifera indica, Cocos nucifera etc. From the 30 homegardens studied, 120 different species of plants were found and these are distributed among 50 Families (Tables 2\&3). The most represented families are Euphorbiaceae, Solanaceae, Rutaceae, Malvaceae, Caesalpiniaceae, Poaceae and Apocynaceae in order of decreasing number of species (Fig. 3). The species composition of homegardens is independent of the size but related to the needs of the owners (Figure 4). 
Table 2: List of plant species found in homegardens in Odeda Area, Southwestern Nigeria.

\begin{tabular}{|c|c|c|c|c|}
\hline Species & Family & Habit & Part(s) used & Use(s) \\
\hline Citrus sinensis & Rutaceae & Tree & Fruit & $f$ \\
\hline Lawsonia inermis & Lythraceae & Tree & Leaf & CS \\
\hline Calotropis procera & Asclepidiaceae & Shrub & Milky latex & fp \\
\hline Jatropha gossipifolia & Euphorbiaceae & Shrub & Leaf & $\mathrm{m}$ \\
\hline Jatropha curcas & Euphorbiaceae & Shrub & Leaf & $\mathrm{m}$ \\
\hline Acalypha ornata & Euphorbiaceae & Herb & Whole plant & or \\
\hline Acalypha ciliata & Euphorbiaceae & Herb & Whole plant & or \\
\hline Aloe vera & Asphodelaceae & Herb & Leaf & or, $\mathrm{m}$ \\
\hline Aloe barbadensis & Asphodelaceae & Herb & Leaf & or. $\mathrm{m}$ \\
\hline Psidium guajava & Myrtaceae & Tree & Fruit/Whole plant & f, sh \\
\hline Ocimum gratissimum & Lamiaceae & Shrub & Leaf & $\mathrm{c}, \mathrm{m}$ \\
\hline Musa paradisiaca & Musaceae & Herb & Fruit & $f$ \\
\hline Musa sapientum & Musaceae & Herb & Fruit & f \\
\hline Corchorus olitorius & Tiliaceae & Herb & Leaf & $f$ \\
\hline Vernonia amygdalina & Asteraceae & Shrub & Leaf & $\mathrm{m}, \mathrm{c}$ \\
\hline Amaranthus hybridus & Amaranthaceae & Herb & Leaf & f \\
\hline Celosia argentea & Amaranthaceae & Herb & Leaf & $f$ \\
\hline Capsicum chinensis & Solanaceae & Shrub & Fruit & C \\
\hline Capsicum fruitescens & Solanaceae & Shrub & Fruit & c \\
\hline Ananas comosus & Bromeliaceae & Herb & Fruit & $f, m$ \\
\hline Carica papaya & Caricaceae & Tree & Fruit/Leaf & $f, m$ \\
\hline Abelmoschus esculenta & Malvaceae & Herb & Fruit & $f, c$ \\
\hline Nicotiana tabacum & Solanaceae & Herb & Leaf & $\mathrm{sn}, \mathrm{m}$ \\
\hline Cajanus cajan & Papilionaceae & Tree & Leaf & $\mathrm{m}$ \\
\hline Zea mays & Poaceae & Grass & Seed & $f$ \\
\hline Dieffenbachia amoena & Araceae & Herb (Cane) & Whole plant & or \\
\hline Theobroma cacao & Sterculiaceae & Tree & Seed & $b$ \\
\hline Citrus medica & Rutaceae & Tree & Fruit & $\mathrm{m}$ \\
\hline Morinda lucida & Rubiaceae & Tree & Leaf & $\mathrm{m}$ \\
\hline Lycopersicon esculentum & Solanaceae & Shrub & Fruit & c. $f$ \\
\hline Cocos nucifera & Arecaceae & Tree & Fruit (Endosperm) & f. $m$ \\
\hline Cymbopogon citratus & Poaceae & Grass & Leaf & $\mathrm{m}$ \\
\hline Ficus exasperata & Moraceae & Tree & Leaf & $\mathrm{m}, \mathrm{sc}$ \\
\hline Mangifera indica & Anacardiaceae & Tree & Fruit & f \\
\hline Bougainvillea speciosa & Nyctaginaceae & Climber & Whole plant & or \\
\hline Tabebuia rosea & Bignoniaceae & Tree & Whole plant & or \\
\hline Bryophillum pinnatum & Crassulaceae & Herb & Leaf/Whole plant & $\mathrm{m}$, or \\
\hline Duranta repens & Verbenaceae & Shrub & Whole plant & or \\
\hline Croton zambesicus & Euphorbiaceae & Tree & Whole plant/Leaf & or, $\mathrm{m}$ \\
\hline Annona muricata & Annonaceae & Tree & Fruit & f \\
\hline Eugenia uniflora & Myrtaceae & Shrub & Whole plant & or \\
\hline Eucalyptus toreliana & Myrtaceae & Tree & Whole plant & or \\
\hline Hibiscus rosa-sinensis & Malvaceae & Shrub & Whole plant & or \\
\hline Caesalpinia pulcherima & Caesalpiniaceae & Shrub & Whole plant & or \\
\hline Delonix regia & Caesalpiniaceae & Tree & Whole plant & or \\
\hline Spondias mombim & Anacardiaceae & Tree & Fruit & $f$ \\
\hline Gossypium hirsutum & Malvaceae & Shrub & Fruit & $\mathrm{m}$ \\
\hline Zingiber officinale & Zingiberaceae & Herb & Rhizome & $\mathrm{m}, \mathrm{c}$ \\
\hline Anacardium occidentalis & Anacardiaceae & Tree & Fruit & $f^{\prime}$ \\
\hline Telfaria occidentalis & Cucurbitaceae & Climber & Leaf & $\mathrm{m}, \mathrm{c}$ \\
\hline Tectona grandis & Verbenaceae & Tree & Whole plant & sh \\
\hline Annona squamosa & Annonaceae & Shrub & Fruit & $f$ \\
\hline Artocarpus communis & Moraceae & Tree & Fruit & $f$ \\
\hline Kalanchoe tomentosa & Crassulaceae & Herb & Whole plant & or \\
\hline Glyphaea brevis & Tiliaceae & Shrub & Stem & ce \\
\hline Citrus aurantifolia & Rutaceae & Tree & Fruit & $\mathrm{m}$ \\
\hline Abrus precatorius & Papilionaceae & Climber & Leaf & $\mathrm{m}$ \\
\hline Newbouldia laevis & Bignoniaceae & Tree & Leaf & ce \\
\hline Ricinus communis & Euphorbiaceae & Shrub & Seed (oil) & $\mathrm{m}$ \\
\hline Cycas circinalis & Cycadaceae & Palm & Whole plant & or \\
\hline Cycas revoluta & Cycadaceae & Palm & Whole plant & or \\
\hline
\end{tabular}


Table 2 (continued).

\begin{tabular}{|c|c|c|c|c|}
\hline Species & Family & Habit & Part(s) used & Use(s) \\
\hline Colocasia esculenta & Araceae & Herb & Corm & $f$ \\
\hline Saccharum officinarium & Poaceae & Culm & Stem & $f$ \\
\hline Citrus reticulata & Rutaceae & Tree & Fruit & f \\
\hline Terminalia catappa & Combretaceae & Tree & Fruit/Whole plant & $f$, sh \\
\hline Basella alba & Chenopodiaceae & Climber & Leaf & C \\
\hline Citrulus lunatus & Cucurbitaceae & Creeper & Fruit & $f$ \\
\hline Sorghum bicolor & Poaceae & Grass & Seed & $f$ \\
\hline Ipomoea batatas & Convolvulaceae & Creeper & Tuber & $f$ \\
\hline Euphorbia milli & Euphorbiaceae & Herb & Whole plant & or \\
\hline Acalypha wilkesiana & Euphorbiaceae & Herb & Whole plant & or \\
\hline Sanseveria laurentii & Liliaceae & Shrub & Whole plant & or \\
\hline Hibiscus sabdarifa & Malvaceae & Shrub & Leaf & $\mathrm{m}$, be \\
\hline Talinum triangulare & Portulacaceae & Herb & Leaf & $\mathrm{C}$ \\
\hline Moringa oleifera & Moringaceae & Tree & Leaf & $\mathrm{m}$ \\
\hline Ficus benjamina & Moraceae & Tree & Whole plant & sh \\
\hline Gmelina arborea & Verbenaceae & Tree & Whole plant & sh \\
\hline Ixora coccinea & Rubiaceae & Shrub & Whole plant & or \\
\hline Ixora Iudiflora & Rubiaceae & Shrub & Whole plant & or \\
\hline Elaeis guinensis & Arecaceae & Tree & Seed (Oil) & $\mathrm{C}$ \\
\hline Murraya paniculata & Rutaceae & Shrub & Whole plant & or \\
\hline Codiaeum variegatum & Euphorbiaceae & Herb & Whole plant & or \\
\hline Thuja occidentalis & Cupressaceae & Tree & Whole plant & or \\
\hline Senna alata & Caesalpiniaceae & Shrub & Leaf & $\mathrm{m}$ \\
\hline Azadiractha indica & Meliaceae & Tree & Leaf & $\mathrm{m}$ \\
\hline Solanum macrocarpon & Solanaceae & Herb & Fruit & $f$ \\
\hline Dioscorea alata & Dioscoreaceae & Climber & Tuber & $f$ \\
\hline Heliotropicum indicum & Boraginaceae & Herb & Leaf & $\mathrm{m}$ \\
\hline Thymus bifida & Lamiaceae & Herb & Leaf & c \\
\hline Leucena leucocephala & Mimosaceae & Tree & Leaf & $\mathrm{m}$ \\
\hline Basella rubra & Chenopodiaceae & Climber & Leaf & $\mathrm{C}$ \\
\hline Parquetina nigrescens & Asclepidiaceae & Climber & Leaf & $\mathrm{m}$ \\
\hline Lactuca taraxacifolia & Asteraceae & Herb & Leaf & $\mathrm{m}$ \\
\hline Glyricedium sepium & Papilionaceae & Tree & Leaf & $\mathrm{m}, \mathrm{sh}$ \\
\hline Solanum dasyphylum & Solanaceae & Shrub & Fruit & $\mathrm{m}$ \\
\hline Talinum paniculata & Portulacaceae & Herb & Leaf & $\mathrm{C}$ \\
\hline Hura crepitans & Euphorbiaceae & Tree & Whole plant & or \\
\hline Senna siamea & Caesalpiniaceae & Tree & Whole plant & sh \\
\hline Agave americana & Amaryllidaceae & Herb & Whole plant & or \\
\hline Indian forma & Lauraceae & Shrub & Whole plant & or \\
\hline Manihot esculentum & Euphorbiaceae & Shrub & Tuber & $f$ \\
\hline Croton variegatum & Euphorbiaceae & Shrub & Whole plant & or \\
\hline Crassocephalum crepidiod & tes Asteraceae & Herb & Leaf & C \\
\hline Canna indica & Cannaceae & Herb & Whole plant & or \\
\hline Euphorbia laterifolia & Euphorbiaceae & Herb & Whole plant & or \\
\hline Mirabilis jalapa & Nyctaginaceae & Herb & Whole plant & or \\
\hline Cordyline terminalis & Liliaceae & Shrub & Whole plant & or \\
\hline Phyllanthus amarus & Euphorbiaceae & Herb & Leaf & $\mathrm{m}$ \\
\hline Thevetia peruviana & Apocynaceae & Shrub & Whole plant & or \\
\hline Polyalthia longifolia & Annonaceae & Tree & Whole plant & or \\
\hline Sesamum indicum & Pedaliaceae & Herb & Seed (Oil) & $\mathrm{m}$ \\
\hline Alstonia boonei & Apocynaceae & Tree & Leaf/Whole plant & $\mathrm{m}, \mathrm{sh}$ \\
\hline Cnidoscolus acontifolius & Euphorbiaceae & Shrub & Leaf & $\mathrm{C}$ \\
\hline Rauvolfia vomitoria & Apocynaceae & Shrub & Leaf & $\mathrm{m}$ \\
\hline Plumera alba & Apocynaceae & Herb & Whole plant & or \\
\hline Cactus spp. & Cactaceae & Herb & Whole plant & or \\
\hline Dracaena manni & Liliaceae & Herb & Whole plant & or \\
\hline Hyptis bracteolate & Lamiaceae & Herb & Leaf & $\mathrm{m}$ \\
\hline Thaumatococcus danielli & Maranthaceae & Herb & Leaf & $\mathrm{m}$ \\
\hline Crecentia cujete & Bignoniaceae & Tree & Fruit & $\mathrm{m}$ \\
\hline
\end{tabular}

Conventions: $\mathbf{m}=$ medicinal, $\mathbf{c}=$ culinary/condimental, or $=$ ornamental, $\mathbf{s h}=$ shade, $\mathbf{s c}=$ scouring, $\mathbf{s n}=$ snuff, $\mathbf{b e}=$ beverage, $\mathbf{c e}=$ ceremonial, $\mathbf{f}=$ food, $\mathbf{c o}=$ cotton, $\mathbf{f p}=$ food processing. 
Bajopas Volume 6 Number 2 December, 2013

Table 3: Plant distribution according to families.

\begin{tabular}{|c|c|}
\hline Family & No of species \\
\hline Euphorbiaceae & 15 \\
\hline Solanaceae & 6 \\
\hline Rutaceae & 5 \\
\hline Apocynaceae & 4 \\
\hline Malvaceae & 4 \\
\hline Caesalpiniaceae & 4 \\
\hline Poaceae & 4 \\
\hline Myrtaceae & 3 \\
\hline Lamiaceae & 3 \\
\hline Asteraceae & 3 \\
\hline Papilionaceae & 3 \\
\hline Rubiaceae & 3 \\
\hline Moraceae & 3 \\
\hline Anacardiaceae & 3 \\
\hline Bignoniaceae & 3 \\
\hline Verbenaceae & 3 \\
\hline Annonaceae & 3 \\
\hline Liliaceae & 3 \\
\hline Asclepidiaceae & 2 \\
\hline Amaranthaceae & 2 \\
\hline Asphodelaceae & 2 \\
\hline Musaceae & 2 \\
\hline Tiliaceae & 2 \\
\hline Araceae & 2 \\
\hline Arecaceae & 2 \\
\hline Nyctaginaceae & 2 \\
\hline Crassulaceae & 2 \\
\hline Cucurbitaceae & 2 \\
\hline Cycadaceae & 2 \\
\hline Portulacaceae & 2 \\
\hline Chenopodiaceae & 2 \\
\hline Lythraceae & 1 \\
\hline Bromeliaceae & 1 \\
\hline Caricaceae & 1 \\
\hline Sterculiaceae & 1 \\
\hline Zingiberaceae & 1 \\
\hline Combretaceae & 1 \\
\hline Convolvulaceae & 1 \\
\hline Moringaceae & 1 \\
\hline Cupressaceae & 1 \\
\hline Meliaceae & 1 \\
\hline Dioscoreaceae & 1 \\
\hline Boraginaceae & 1 \\
\hline Mimosaceae & 1 \\
\hline Amaryllidaceae & 1 \\
\hline Lauraceae & 1 \\
\hline Cannaceae & 1 \\
\hline Pedaliaceae & 1 \\
\hline Cactaceae & 1 \\
\hline Maranthaceae & 1 \\
\hline
\end{tabular}




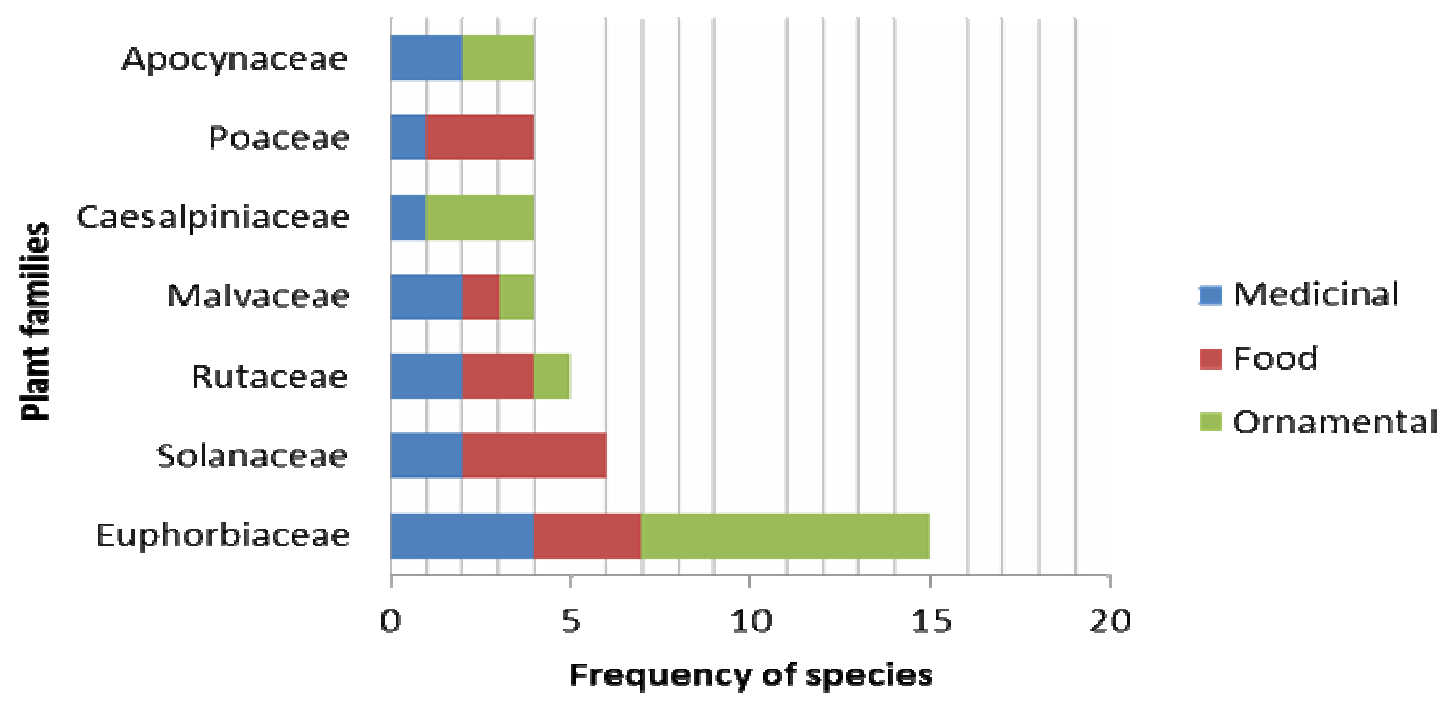

Fig. 3: Most represented botanical families and their reported uses by frequency.

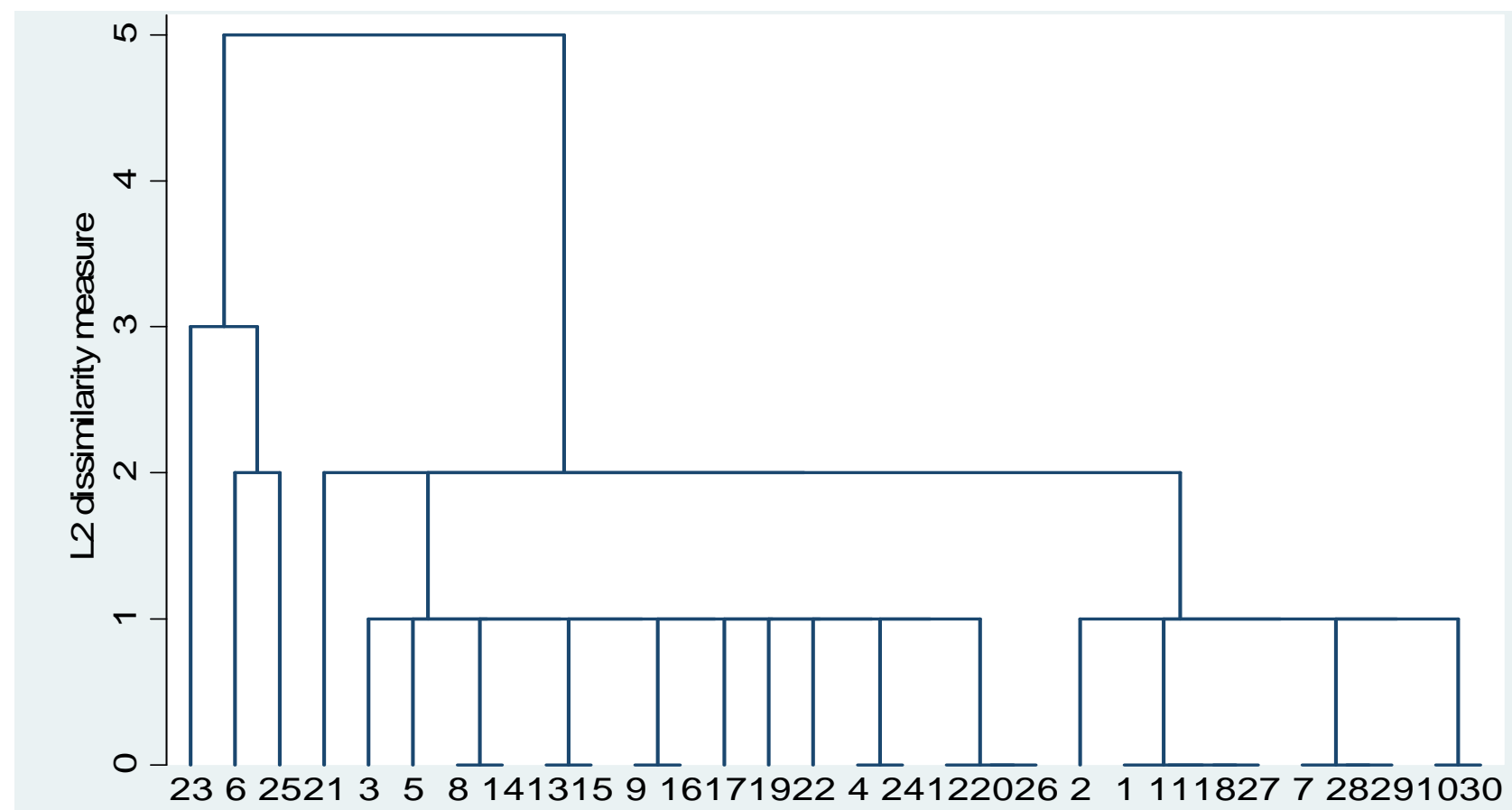

Fig. 4: Cluster analysis showing relationships between the $\mathbf{3 0}$ homegardens based on homegarden size and species composition.

Two groups of plants were found in the studied sites. Group 1: plants grown and maintained. Group 2: naturally established plants but maintained. In the latter case, plants cited were Ficus exasperata, Nicotiana tabaccum, Newbouldia laevis, Gmelina arborea, Azadirachta indica, Glyricedium sepium. Others include Talinum triangulare and Phyllanthus amarus (only used, not maintained). Some of the plants are grown because of their seasonal importance. Such plants include Zea mays, Saccharum officinarium, Sorghum bicolor and Dioscorea species. Variation in species composition was not large throughout the 30 homegardens studied. Most of the homegardens considered have common plant species with the exception of few; this has ecological implication. Taxa such as Musa spp., Vernonia amygdalina, Citrus spp., Psidium guajava and Terminalia catapa were found to be the common food/medicinal plants across homegardens surveyed and had the highest density. All plant life forms were duly represented (Table 4) with herb taking the largest share $(31.6 \%)$ and culm $(0.8 \%)$ the lowest. Table 5 shows the plant parts used and their frequencies. The leaves form the major part of plant used followed by whole plant - as ornamentals. Ornamental species such as Delonix regia, Dieffenbachia amoena, Acalypha ornata, A. ciliata, Aloe vera etc. are often arranged in courtyards or at the frontage of buildings. 
Table 4: Plant life form and their frequency

\begin{tabular}{lc}
\hline Habit & Frequency \\
\hline Herb & 38 \\
Tree & 37 \\
Shrub & 30 \\
Climber & 7 \\
Grass & 3 \\
Creeper & 2 \\
Palm & 2 \\
Culm & 1 \\
\hline
\end{tabular}

Table 5: Frequency of plant parts used

\begin{tabular}{lc}
\hline Plant part & Frequency \\
\hline Leaves & 42 \\
Whole plant & 39 \\
Fruits & 25 \\
Seeds & 6 \\
Stem & 2 \\
Tuber & 3 \\
Milky latex & 1 \\
Corm & 1 \\
Rhizome & 1 \\
\hline
\end{tabular}

\section{DISCUSSION}

Ethnobotany makes clear the connection between human cultural practices and plant utilization. In the study of Ethnobotany today, homegardens and their roles as biodiversity conservation centres cannot be over-emphasized. Gispert and Gomez (1986) reported that from ancient times, kitchen gardens, house gardens or homegardens have played fundamental roles in the supply of food products. Plant domestication represents a major achievement. The study of indigenous cultivation, food production, local medicinal knowledge and varied use of vegetal species has implications for food nutrient augmentation as well as discovering new medicines. The diverse use of plants indicated in this study point to the fact that gardens have been used to cultivate not only vegetables, but also medicinal and other miscellaneous uses. Cosmetics, scouring and ceremonial are classified in this work as miscellaneous or rare uses. All the alimentary species from the family Lamiaceae were used as condiments, indicating their important role in diversifying the flavour of food. The gardens studied are subsistence in nature [based on their mean size and according to the classification of Fernandes and Nair (1986)]. Homegardens have the function of guaranteeing subsistence as well as complementing the household income, for instance, taxa such as Amaranthus and Celosia species are cultivated on small commercial scale. The most representative families in this study have also been cited in previous studies that were focused on old urban homegardens by Eichemberg et al. (2009) and Albuquerque et al. (2005). The most widely used medicinal plants (Vernonia amygdalina, Jatropha spp., Cympobogon citratus) have again been implicated in this study. The leaves form the most used plant part. This is in line with similar ethnobotanical studies by Adekunle (2008), Ayodele (2005) and Erinoso and Aworinde (2012).

The physical appearance of homegardens is species composition dependent. The changes in structure and function are primarily related to subsistence as homegardens function to fulfill the varied daily needs of the owner; other factors include improvement programs such as intensification and commercialization (Karyono, 2000). The horizontal and vertical arrangements of species form the two structural components of homegardens (Millat et al., 1996). A systematic distribution pattern was not recognized in this study as against the pattern reported by Caballero (1992) as some gardens have plant species haphazardly distributed; typical of random pattern. This is in line with the submission of Karyono (2000) that homegarden may present the appearance of a haphazard combination of trees, shrubs, herbs, climbers and creeping plants. The lack of unified methodology in the study of homegarden (Albuquerque et al., 2005) makes homegarden structure to vary in different regions (Soemarwoto et al., 1985). Women play a significant role in homegarden maintenance, although the idea of establishment is solely that of men. This is evidenced from the number of females interviewed. They tend to maintain the aesthetic feature of their environment. Most of the ornamentals especially the herbaceous species are potted. Not all the medicinal plants sighted are grown. Some were naturally established but later maintained when the use value was discovered. These plant species may have been introduced by agents of dispersal such as birds, wind and explosive mechanism, especially those ones that are propagated by seeds.

\section{CONCLUSION}

This study has once again proved that homegardens are useful sources of plant germplasm. But together with the germplasm conserved in the homegardens, as suggested by Valle (2000), it is extremely important to maintain the knowledge regarding these species and varieties. And as such new generations should be encouraged to recover and re-energize the productive capacity of homegardens. 


\section{Acknowledgement}

The authors would like to thank all the people interviewed in the rural/semi-urban communities of

\section{REFERENCES}

Adekunle, M.F. (2008): Indigenous uses of plants leaves to treat malaria fever at Omo Forest Reserve (OFR), Ogun State, Nigeria. Ethiopia Journal of Environmental Studies and Management, 1(1): 31-35.

Agelet, A. Bonet, M.A. and Valles, J. (2000): Homegardens and their role as a main source of medicinal plants in mountain regions of Catalonia (Iberian Peninsula). Economic Botany, 53(4): 295-309.

Albuquerque, U.P., Andrade, L.H.C. and Caballero, J. (2005): Structure and floristics of homegardens in Northeastern Brazil. Journal of Arid Environment, 62(3): 491-506.

Amaral, C.N. and Guarim-Neto, G. (2008): Os quintais como espaços deconservação e cultivo de alimentos: um estudo na cidade de Rosário Oeste (Mato Grosso, Brasil). Boletim do Museu Paraense Emílio Goeldi, 3(3): 329341.

Ayodele, A.E. (2005): The medicinally important leafy vegetables of South-Western Nigeria. (http//www.siu.edu/ebl/leaflets/ayodele/html ) .

Babu, K.S., Jose, D. and Gokulapalan, C. (1982): Species diversity in a Kerala home garden. Agroforestry Today, 4: 15-20.

Brito, M.A. and Coelho, M.F.B. (2000): Os quintais agrofl orestais em regiões tropicais unidades auto sustentáveis. Revista Agricultura Tropical, 4(1): 1-21.

Caballero, J. (1992). Maya homegardens: past, present and future. Etnoecológica, 1: 35-54.

Das, T. and Das, A.K. (2005): Inventorying plant biodiversity in homegardens: A case study in Barak valley, Assam, North East India. Current Science, 89: 155-163.

Dean, A.G., Dean, A.J. and Coloumbier, D. (1994): Epi info: A word processing database and statistics program for epidemiology on microcomputers. Centre for disease control and prevention, Atlanta, GA, USA.

Eichemberg, M.T., Amorozo, M.C. and Moura, L.C. (2009): Species composition and plant use in old urban homegardens in Rio Claro, Southeast of Brazil. Acta Botanica Brasilia, 23(4): 1057-1075.

Erinoso, S.M. and Aworinde, D.O. (2012): Ethnobotanical survey of some medicinal plants used in traditional health care in Abeokuta areas of Ogun State, Nigeria. African Journal of Pharmacy and Pharmacology, 6(18): 1352-1362.

Fernandes, E.C.M. and Nair, P.K.R. (1986): An evaluation of the structure and function of tropical homegardens. Agoforestry Systems, 21: 279-310.
Odeda for the opportunity to use their homegardens as study sites; for information given as well as hospitality and accommodation.

Gispert, M. and Gomez, A. (1986): Plantas medicinales silvestres: el proceso adquisicon, transmision y colectivizacion del conocimiento vegetal. Biotica, 11(2): 113-125.

Hoogerbrugge, I.D. and Fresco, L.O. (1993): Homegarden Systems: Agricultural Characteristics and Challenges. International Institute for Environment and Development (Gatekeeper series, 39), London.

Karyono (2000): Traditional homegarden and its transforming trend. Jurnal Bionatura, 2(3): 117-124.

Lamont, S.R., Eshbaugh, W.H. and Greenber, G. (1999): Species composition, diversity and use of homegardens among three amazonian villages. Economic Botany, 53: 312-326.

Millat, E., Mustafa, M.D., Hall, J.B. and Teklehaimanot, Z. (1996): Structure and floristics of Bangladesh homegardens. Agroforestry Systems, 33(3): 263-280.

NBS (2006): National Bureau of Statistics, National Population Commission, Abuja, Nigeria.

Padoch, C. and De-Jong, W. (1991): The house gardens of Santa Rosa: diversity and variability in an amazonian agricultural system. Economic Botany, 45: 166-175.

Semedo, R.J. and Barbosa, R.I. (2007): Árvores frutíferas nos quintais urbanos de Boa Vista, Roraima, Amazônia brasileira. Acta Amazonica, 37(4): 497-504.

Soemarwoto, O. (1987): Home gardens: a traditional agroforestry system with a promising future. In: Steppler HA, Nair PKR (eds.) Agrofrestry: A Decade of Development. ICRAF, Nairobi, Kenya.

Soemarwoto, O. and Conway, G.R. (1991): The javanese homegarden. Journal of Farming Systems, Research and Extension, 2(3): 95117.

Soemarwoto, O., Soemarwoto, I., Soekartadiredja, K.E.M. and Ramlan, A. (1985): The javanese home garden as an integrated agroecosystem. Food Nutrition Bulletin, 7(3): 4447.

Taiwo, A.M., Adeogun, A.O., Olatunde, K.A. and Adegbite, K.I. (2011): Analysis of Groundwater Quality of Hand-Dug Wells in Peri-Urban Area of Obantoko, Abeokuta, Nigeria for Selected Physico-Chemical Parameters. The Pacific Journal of Science, 12(1): 527-534.

Valle, T.L. (2000): Coleta de germoplasma de plantas cultivadas. In: Amorozo, M. C M.; Ming, L. C. \& Silva, S. P. (Ed.). Métodos de coleta e análise de dados em etnobiologia, etnoecologia e disciplinas correlatas. UNESP. 